\title{
Agreements within Government Entities and Conspiracies under $\S 1985(3)-A$ New Exception to the Intracorporate Conspiracy Doctrine?
}

\author{
Geoff Lundeen Carter $\dagger$
}

One of the primary purposes of conspiracy law is to punish conspirators for the enhanced danger they pose to society when they agree to combine resources and act unlawfully. The goals of conspiracy law conflict, however, with the common law tradition of regarding corporations as single, unitary actors. Courts resolve this conflict in some areas of law by applying the intracorporate conspiracy doctrine. Under this doctrine, the actions of two employees of a single corporation cannot constitute a legal "conspiracy," so long as the employees are acting within the scope of their employment. ${ }^{1}$

The intracorporate conspiracy doctrine is controversial because it limits society's ability to respond to the enhanced danger posed by individuals who form agreements to act unlawfully. For example, in antitrust law, the doctrine renders virtually all intracorporate discussions nonconspiratorial as a matter of law. Thus, $\S 1$ of the Sherman Act ${ }^{2}$ cannot reach agreements between employees of a single corporation, even if those agreements constitute unreasonable restraints of trade. By contrast, courts do not apply the intracorporate conspiracy doctrine in criminal conspiracy cases, in part because criminal conspiracies pose threats too significant to allow the corporate structure to shield the employees from criminal liability. ${ }^{3}$

† B.A. 1992, Stanford University; J.D. Candidate 1996, The University of Chicago.

1 Under the intracorporate conspiracy doctrine, agreements between employees of a single government entity do not constitute conspiracies in the legal sense. See, for example, Gladden v Barry, 558 F Supp 676, 679 (D DC 1983) (stating that "the weight of authority holds that there can be no conspiracy if the conduct complained of is essentially a single act by a single entity").

2 Sherman Act, ch 647, § 1, 26 Stat 209 (1890), codified at 15 USC $\$ 1$ (1994).

3 For the purposes of this Comment, the phrase "antitrust liability" refers to both civil and criminal penalties under $\$ 1$ of the Sherman Act. The term "criminal conspiracy" refers to all other conspiracies to commit crimes (excluding antitrust violations). 
The federal courts disagree about whether the intracorporate conspiracy doctrine should apply to civil rights conspiracy claims brought under $\S 1985(3)$ of the Ku Klux Klan Act of 1871. ${ }^{4}$ A majority of the federal courts, relying on antitrust precedents, has held that the intracorporate conspiracy doctrine does apply to $\S 1985$ (3) claims. A minority of the federal courts, however, has relied on criminal conspiracy precedents to hold that it does not. Lost in this debate, however, is the question whether the doctrine should apply when the alleged conspiracy occurred within a single government entity, rather than within a single corporation. ${ }^{5}$

This Comment argues that the intracorporate conspiracy doctrine should not prevent plaintiffs from bringing § 1985(3) actions against employees of a single government entity. ${ }^{6}$ As one of the statutes designed to enforce the provisions of the Fourteenth Amendment, § 1985(3) embodies the principle that states may not deny individuals equal protection of the laws. ${ }^{7}$ Civil rights conspiracies within government entities pose a special

4 Section 1985(3) reads, in pertinent part:

If two or more persons ... conspire ... for the purpose of depriving ... any person or class of persons of the equal protection of the laws, ... or for the purpose of preventing or hindering the constituted authorities of any State ... from giving or securing to all persons ... the equal protection of the laws ... whereby another is injured in his person or property,... the party so injured or deprived may have an action for the recovery of damages ... against any one or more of the conspirators.

42 USC § 1985(3) (1994).

s The term "single government entity" refers to any cohesive governmental body, whether local, state, or federal. Each of the following is an example of a single government entity: the City of Chicago, the Environmental Protection Agency, and the University of Tennessee.

- This Comment focuses primarily on alleged conspiracies involving agreements between at least two employees; it does not address directly whether plaintiffs should be able to establish conspiracies by claiming that the corporation conspired with a single employee. For an analysis of whether a single employee can conspire with a corporation, see Susan J. Hoffmann, Comment, Corporate Criminal Liability for Intracorporate Conspiracy, 72 Ky L J 225 (1983); Note, Intracorporate Conspiracies Under 42 USC \$1985(c), 92 Harv L Rev 470, 487-89 (1978).

7 Although $\S 1985(3)$ applies to government actions, the statute was primarily enacted as a means of reaching private conspiracies to deny equal protection of the laws. Ken Gormley, Private Conspiracies and the Constitution: A Modern Vision of 42 U.S.C. Section 1985(3), 64 Tex L Rev 527, 536-40 (1985). Congress passed the Ku Klux Klan Act of 1871 , ch 22,17 Stat 13, codified at 42 USC $\$ 1985(3)$ (1994), in response to the efforts by the Ku Klux Klan to disrupt the operations of local and state governments. Relying on $\S 5$ of the Fourteenth Amendment, Congress passed the Act to create a federal cause of action for Klan activities that denied equal protection of the laws. Gormley, 64 Tex L Rev at 530-40. 
threat to that principle because the conspirators directly control the government, which is charged with both administering the laws and guaranteeing their equal application.

Section I of this Comment describes the intracorporate conspiracy doctrine and discusses the relevant case law. Section II shows that the legislative history and purpose of $\S 1985(3)$ militate against the application of that doctrine to conspiracies within a single government entity. Section III argues that, despite some judicial language to the contrary, antitrust precedents provide a poor legal footing for applying the intracorporate conspiracy doctrine to $\S 1985(3)$ claims against employees of a single government entity. Because such an application would frustrate the purposes underlying $\S 1985(3)$, courts should refuse to apply the intracorporate conspiracy doctrine in this context.

\section{Framing the Dispute}

\section{A. The Intracorporate Conspiracy Doctrine}

The intracorporate conspiracy doctrine offers a solution to the conflict between conspiracy law and the common law rule that corporations are single, unitary actors. Under the doctrine, a plaintiff cannot establish the multiplicity of actors necessary for a conspiracy by pointing to two or more employees of a single corporation; the theory assumes the employees are acting on behalf of the corporation, which is a single entity. ${ }^{8}$ Because the

8 See Kathleen F. Brickey, 1 Corporate Criminal Liability: A Treatise on the Criminal Liability of Corporations, Their Officers and Agents $\S 6: 20$ at 211-13 (Callaghan 1984). For the seminal case discussing this doctrine, see Nelson Radio \& Supply Co. $v$ Motorola, Inc., 200 F2d 911, 914 (5th $\mathrm{Cir} 1952$ ) ("A corporation cannot conspire with itself any more than a private individual can, and it is a general rule that the acts of the agent are the acts of the corporation."). See also Jon L. Craig, ed, 1 Civil Actions Against State and Local Government-Its Divisions, Agencies, and Officers \$ 8.46 at 763-67 (Shepard's 2d ed 1992) (explaining doctrine and listing cases). Prior to Nelson, courts split on the doctrine and its application in the antitrust context. Compare United States $v$ American National Stores Co., 172 F 455, 463 (C C S D Ga 1909) (instructing jurors that "a corporation may not conspire with its own officers"); Arthur $v$ Kraft-Phenix Cheese Corp, 26 F Supp 824, 830 (D Md 1937) (explaining that agreements between defendant corporation and its own agents were insufficient to establish a conspiracy), with United States $v$ Bausch \& Lomb Optical Co., 321 US 707, 723 (1944) (suggesting that defendant corporation's agreements with its own agents violated the Sherman Act); Patterson v United States, 222 F 599, 618 (6th $\mathrm{Cir} 1915$ ) (explaining that $\S 1$ of the Sherman Act reaches agreements "between the officers and agents of a [corporation] on its behalf against a competitor"). The Supreme Court did not decide this issue until 1984, when it stated that the doctrine does apply to the Sherman Act. Copperweld Corp $v$ Independence Tube Corp, 467 US 752, 769 (1984). The Court, however, did not address whether the intracorporate conspiracy doctrine applies to $\S 1985(3)$. 
doctrine's respect for this common law conception of the corporation comes at the expense of conspiracy liability, a court's decision to apply it to a given body of law is often controversial.

\section{Conspiracy law and the problem of group danger.}

Both courts and commentators agree that conspiracy law serves two societal purposes. First, as an inchoate offense, a conspiracy comprises the mere planning of a crime; as such, authorities can arrest conspirators before they actually commit their intended offense. ${ }^{9}$ Second, conspiracy law addresses the special problem of group danger by imposing extra punishment on those who threaten society through concerted group action. ${ }^{10}$ The intracorporate conspiracy doctrine interferes with this second purpose because it does not view agreements between employees of single corporations as concerted group action. ${ }^{11}$

The group danger associated with a conspiracy poses a substantial threat to society because individuals who conspire may pool their resources, may commit more complex (and less easily detected) crimes, and are more likely to complete the planned crime due to the pressure inherent in group activity. ${ }^{12}$ In contrast, a single actor may abort his plans to commit a crime at any time; he need only change his own mind. As the Supreme Court explained in Callanan v United States:

[C]ollective criminal agreement-partnership in crime - presents a greater potential threat to the public than individual [acts]. Concerted action both increases the likelihood that the criminal object will be successfully attained and decreases the probability that the individuals involved will depart from their path of criminality. ${ }^{13}$

Because the danger posed by concerted action is substantial, courts often hold defendants liable for both the target offense and the conspiratorial agreement itself. ${ }^{14}$

- Paul Marcus, Prosecution and Defense of Criminal Conspiracy Cases $\$ 1.04[2]$ at 117 to 1-22 (Matthew Bender 1990).

10 Id § 1.04[3] at 1-22 to 1-26.

11 Brickey, 1 Corporate Criminal Liability $\$$ 6:20 at 211-13 (cited in note 8). See also text accompanying notes $20-23$.

12 Marcus, Prosecution and Defense § 1.04[3] at 1-22 to 1-23 (cited in note 9).

13364 US 587, 593 (1961). See also United States $v$ Rabinowich, 238 US 78, 88 (1915) (Conspiracy "is an offense of the gravest character, sometimes quite outweighing, in injury to the public, the mere commission of the contemplated crime.").

${ }^{14}$ See, for example, Callanan, 364 US at 594 (" $[T]$ he danger which a conspiracy 
2. Corporations as single, unitary actors.

The unique dangers of group activity make a strong case for treating all such activity harshly. However, these dangers may not be present to the same degree where the activities of two employees of the same corporation are at issue. Under the common law, corporations are created by the state, which generally grants them special privileges in order to facilitate business activities. ${ }^{15}$ Corporations can bring lawsuits, own property, and engage in a host of other activities commonly attributed to natural persons. ${ }^{16}$ As one aspect of their special legal status, courts have generally held that although corporations often employ several individuals, the law regards them as single persons. ${ }^{17}$ Consequently, corporations can be directly sued for harms caused by their employees, provided the employees were acting within the scope of their employment when the harm occurred. ${ }^{18}$

The theory of the corporation as a single, unitary actor sometimes conflicts with conspiracy law. Specifically, when faced with an agreement between two or more employees of a single corporation, a court must decide whether to adhere to corporate law principles, and consider the employees' actions those of a single entity, or to follow the tenets of conspiracy law, and treat the actions as those of separate actors. ${ }^{19}$

generates is not confined to the substantive offense which is the immediate aim of the enterprise.").

${ }_{15}$ Brickey, 1 Corporate Criminal Liability $\S 2: 02$ at 16 (cited in note 8). See also W.S. Holdsworth, 3 A History of English Law 469-90 (Little, Brown 1923) (explaining the historical understanding of corporations).

${ }_{16}$ Brickey, 1 Corporate Criminal Liability § 2:04 at 20 (cited in note 8); Holdsworth, 3 History of English Law at 487-89 (cited in note 15).

${ }_{17}$ In 1682, for example, the city of London was forced to forfeit its charter as a result of the misconduct of its officials. The King $v$ City of London, 8 Howell St Tr 1039, 1283 (KB 1682). See also William M. Blackstone, 1 Commentaries $* 456$ (The common law of England treats a corporation as one person before the law.); Brickey, 1 Corporate Criminal Liability \$ 2:04 at 20-23 (cited in note 8) (outlining difficulties of developing a theory of corporate liability); Harry Henn and John R. Alexander, Laws of Corporations $\S 9$ at 17-19 (West 3d ed 1983) (reviewing history of common law's treatment of corporations).

18 Brickey, 1 Corporate Criminal Liability $\$ 1: 04$ at 8-9 (cited in note 8). See also The Queen $v$ Great North of England Railway, 115 Eng Rep 1294, 1298 (QB 1846) (holding that under certain circumstances corporations could be held liable for acts taken by their employees).

${ }_{19}$ See Brickey, 1 Corporate Criminal Liability § 6:11 at 183-84 (cited in note 8). 
3. Resolving the conflict-the intracorporate conspiracy doctrine.

The intracorporate conspiracy doctrine resolves the conflict between conspiracy law and the common law treatment of corporations by holding that two or more employees of the same corporation do not constitute a multiplicity of actors, and therefore their actions cannot constitute a conspiracy as a matter of law. ${ }^{20}$ That is, an agreement between two agents of a single corporation is the functional equivalent of an agreement between an individual and himself. ${ }^{21}$

The courts do not, however, view the intracorporate conspiracy doctrine as a hard-and-fast rule. For example, courts have applied the doctrine in the antitrust context because the danger of chilling legitimate business decisions is substantial. In contrast, courts evince no such concern about chilling effects in other contexts, such as extortion or bribery. ${ }^{22}$ In other words, if the societal interest in protecting the corporate decision-making process outweighs the societal interest in combating the group danger posed by conspiracies, which is seldom the case in the criminal law context, courts are likely to apply the doctrine. Thus, in the antitrust context, where the interest in protecting the corporate decision-making process generally takes precedence over the marginal group danger presented by intracorporate agreements to restrain trade, courts uniformly apply the intracorporate conspiracy doctrine. ${ }^{23}$ However, while the scope of the doctrine is fairly well settled in the criminal and antitrust areas, courts remain divided over the extent to which it should apply in civil rights law.

B. Section 1985(3), the Federal Courts, and the Intracorporate Conspiracy Doctrine: An Ongoing Dispute

Although Congress passed $\S 1985(3)$ in 1871 , the statute remained dormant for over one hundred years after its enactment because courts interpreted it as applying only to cases involving state action. ${ }^{24}$ In Collins $v$ Hardyman, for example, the

${ }^{20}$ Id $\S 6: 20$ at 211-13.

${ }_{21}$ Id. See also Nelson Radio \& Supply Co. $v$ Motorola, Inc., 200 F2d 911, 914 (5th Cir 1952) ("A corporation cannot conspire with itself any more than a private individual can.").

22. Brickey, 1 Corporate Criminal Liability $\$ 6: 21$ at 217-18 (cited in note 8).

${ }^{23}$ Id. See also Section III.A.

24 Civil rights statutes passed during the Reconstruction, such as $\S 1985(3)$, fell into 
Supreme Court held that $\S 1985$ (3) generally did not apply to wholly private conspiracies. ${ }^{25}$ The Court reasoned that because $\S$ 1985(3) targeted only conspiracies that deprive individuals of their right to equal protection of the laws, it did not cover wholly private conspiracies, which usually do not alter the basic rights that individuals possess under the law. ${ }^{26}$

The Supreme Court revived litigation under \& 1985(3), however, when it held in Griffin $v$ Breckenridge that the statute extends to private conspiracies as well as to conspiracies involving state action. ${ }^{27}$ Quoting from the statute, the Court held that plaintiffs can establish conspiracies under § 1985(3) if their complaints allege:

[T] ]hat the defendants did (1) "conspire ..." (2) "for the purpose of depriving, either directly or indirectly, any person or class of persons of the equal protection of the laws ..." (3) [that the defendants committed] "any act in furtherance of the object of [the] conspiracy," whereby another was (4a) "injured in his person or property" or (4b) "deprived of having and exercising any right or privilege of a citizen of the United States. ${ }^{28}$

Following Griffin, the federal courts were flooded with cases brought by people claiming injuries resulting from conspiracies to violate civil rights, ${ }^{29}$ and the courts undertook the task of defining the parameters of the four elements required for a cause of action under $\S 1985(3)$. Much of the debate centered around the conspiracy element, with the courts dividing over whether plaintiffs could establish conspiracies where the defendants were all employees of the same corporations.

disuse after a series of Supreme Court decisions found a number of the new statutes unconstitutional. See, for example, Civil Rights Cases, 109 US 3, 26 (1885) (striking down Civil Rights Act of 1875 as impermissibly reaching private acts when Fourteenth Amendment only allows regulation of state action). See also Gormley, 64 Tex L Rev at 541-46 (cited in note 7) (explaining how $\$ 1985(3)$ fell into disuse).

25341 US 651, 661 (1951).

${ }^{26}$ Id at 661-62. Justice Jackson concluded that "[s]uch private discrimination is not inequality before the law unless there is some manipulation of the law or its agencies to give sanction or sanctuary for doing so." Id at 661. Jackson did concede, however, that $\S$ 1985(3) might cover a private conspiracy that was of such a magnitude that it effectively denied individuals their right to equal protection of the laws. Id at 662 .

27403 US 88, 101 (1971).

${ }^{28}$ Id at 102-03, quoting 42 USC $\S 1985(3)$ (second alteration in original).

20 See, for example, Dombrowski v Dowling, 459 F2d 190, 196 (7th Cir 1972); Girard $v$ 94th Street and Fifth Avenue Corp, 530 F2d 66, 72 (2d Cir 1976). See also Note, 92 Harv $\mathrm{L}$ Rev at 472-77 (cited in note 6) (reviewing post-Griffin case law). 
1. Majority view: The intracorporate conspiracy doctrine applies to § 1985(3).

The majority of the federal circuits has opted to apply strictly the intracorporate conspiracy doctrine to litigation under $\S 1985$ (3). The Seventh Circuit set the standard in Dombrowski v Dowling, when it stated: "[T] or more persons ... conspire ...' is not satisfied by proof that a discriminatory business decision reflects the collective judgment of two or more executives of the same firm. ${ }^{.30}$ Applying this reasoning, the court denied the plaintiff's § 1985(3) claim, holding that the plaintiff failed to establish the existence of a conspiracy. ${ }^{31}$ Since this landmark decision, a number of the federal circuits have followed Dombrowski and applied the intracorporate conspiracy doctrine to $\S 1985(3)$ claims. ${ }^{32}$

The heavy reliance of the majority of the federal circuits on Dombrowski is troubling because that court offered little explanation for its application of the intracorporate conspiracy doctrine to $\S 1985$ (3). The Dombrowski court addressed the doctrine in one short paragraph of its opinion, and merely stated the doctrine without explaining why it should be applied in the context of civil rights law. ${ }^{33}$

The emergence of Dombrowski as a precedent for the application of the intracorporate conspiracy doctrine in the civil rights context is particularly surprising in light of the Seventh Circuit's dicta in that case. Specifically, the court left the door open to § 1985(3) plaintiffs injured by intracorporate conspiracies by stating that "[w]e do not suggest that an agent's action within the scope of his authority will always avoid a conspiracy finding. ${ }^{34}$

30 459 F2d 190, 196 (7th Cir 1972).

31 Id.

32 Cases involving single government entities alone constitute a substantial line. See, for example, Hull v Cuyahoga Valley Joint Vocational Sch Dist. Bd of Educ., 926 F2d 505, 509-10 (6th Cir 1991) (Intracorporate conspiracy doctrine bars § 1985(3) claims against local school board and officials.); Moody $v$ Jefferson Parish School Board, 803 F Supp 1158, 1166 (E D La 1992), aff'd on other grounds, 2 F3d 604, 606 (5th Cir 1993) (same); Runs After $v$ United States, 766 F2d 347, 354 (8th Cir 1985) (Intracorporate conspiracy doctrine applies to Native American tribal council, a quasi-governmental body.); Edmonds $v$ Dillin, 485 F Supp 722, 728-29 (N D Ohio 1980) (Intracorporate conspiracy doctrine bars $\S 1985$ (3) claim against city and its officials.); Gladden v Barry, 558 F Supp 676, 679 (D DC 1983) (same); Lieberman $v$ Gant, 474 F Supp 848, 875 (D Conn 1979), aff'd, 630 F2d 60 (2d Cir 1980) (Doctrine bars § 1985(3) claims against state university and officials.).

$33459 \mathrm{~F} 2 \mathrm{~d}$ at 196.

34 Id (emphasis added). The court did not appear to view the fact that the alleged conspiracy was intracorporate as dispositive. Instead, the court indicated that it viewed the frequency of the alleged discriminatory acts as also an important factor, stating: "[I]f 
Indeed, some courts, perhaps encouraged by this disclaimer, have seized on the Dombrowski court's reference to a "single act" of discrimination as a basis for rejecting the application of the intracorporate conspiracy doctrine where multiple discriminatory acts are involved..$^{35}$ Courts allowing for this exception find the presence of multiple acts to be more indicative of a conspiracy than single acts such as the "simple ratification of a managerial decision by directors. ${ }^{136}$ This exception has been strongly criticized, however, on the basis that the "multiple acts" exception diverts attention away from the central issue in conspiracy law, which is whether there was indeed an agreement between a plurality of individuals. ${ }^{37}$ Nevertheless, in light of the ambiguities in Dombrows $k i{ }^{38}$ it seems odd that the federal courts now routinely cite to Dombrowski as establishing a blanket rule that the intracorporate conspiracy doctrine applies to $\S 1985(3) .{ }^{39}$

the challenged conduct is essentially a single act of discrimination by a single business entity, the fact that two or more agents participated ... will normally not constitute the conspiracy contemplated by this statute." Id (emphasis added).

${ }^{35}$ See Stathos $v$ Bowden, 728 F2d 15, 21 (1st Cir 1984) (stating "a series of acts over time goes well beyond" the exception); Rackin $v$ University of Pennsylvania, 386 F Supp 992 (E D Pa 1974) (explaining Dombrowski does not apply where there are multiple acts of discrimination).

${ }^{36}$ Stathos, 728 F2d at 21.

37 In Coley $v M \& M$ Mars, Inc., for example, the court explained that there is a "conceptual difficulty with the idea ... that the number of discriminatory acts can create a conspiracy although each act is committed by a single entity." $461 \mathrm{~F}$ Supp 1073, 1076 (M $D$ Ga 1978). See also Weaver $v$ Gross, 605 F Supp 210, 214-15 (D DC 1985) (explaining that the relevant consideration is whether the employees were acting within the scope of their employment).

${ }^{38}$ In addition to the confusion over the significance of multiple acts, courts also puzzle over when a conspiracy is in fact intracorporate. Specifically, some courts allow causes of action under $\S 1985$ (3) in cases where one or more of the defendant employees acted outside the scope of employment. See Girard $v$ 94th Street and Fifth Avenue Corp, 530 F2d 66, 72 (2d Cir 1976); Garza v City of Omaha, 814 F2d 553, 556 (8th Cir 1987); Edmonds, 485 F Supp at 729; Weaver, 605 F Supp at 214-15. According to these courts, when a defendant employee acts outside the scope of his employment, that employee becomes an independent actor, capable of conspiring with others. See, for example, Garza, 814 F2d at 556 (Employee acted outside scope of employment when acts were done for personal reasons.). This rule is unreliable and seldom applied, however, because the analysis is highly fact specific and because most courts simply view all acts by employees in their official capacities as within the scope of employment. See Girard, 530 F2d at 7172; Fallis $v$ Dunbar, 386 F Supp 1117, 1121 (N D Ohio 1974), aff'd, 532 F2d 1061 (6th Cir 1976).

39 Another panel of the Seventh Circuit employed a different rationale in applying the intracorporate conspiracy doctrine to $\S 1985(3)$. In Travis $v$ Gary Community Mental Health Center, Inc., the court held that the doctrine should apply because it was an established common law rule when § 1985(3) was enacted in 1871. 921 F2d 108, 110 (7th Cir 1990). On whether it was so established, see text accompanying notes 56-73. 
2. Minority view: The intracorporate conspiracy doctrine does not apply to $\S 1985(3)$.

A minority of the federal circuits has held that the intracorporate conspiracy doctrine has no application in the context of $\S 1985(3)$ civil rights litigation. ${ }^{40}$ In Novotny $v$ Great American Federal Savings \& Loan Association, the Third Circuit rejected all three of the defendant's arguments for such an application. ${ }^{41}$ In rendering its decision, the court first reasoned that neither the plain meaning nor the legislative history of the statute explicitly called for the application of the intracorporate conspiracy doctrine. Second, it explained that nothing in the "general tenets of conspiracy theory" prevented it from finding conspiracies within corporations. ${ }^{42}$

Finally, the court rejected the defendant's argument that the corporate entity shielded corporate employees from § 1985(3) liability. ${ }^{43}$ The court noted that although the intracorporate conspiracy doctrine protects employees from liability for conspiracy in antitrust law, courts rarely apply the doctrine outside of its original, antitrust context. The court reasoned that while the doctrine serves a valuable purpose in antitrust law by facilitating competition and protecting the corporate decision-making process, it does not serve a similar purpose in civil rights law. ${ }^{44}$

40 See Novotny $v$ Great American Federal Savings \& Loan Association, 584 F2d 1235, 1256-59 (3d Cir 1978) (en banc), rev'd on other grounds, 442 US 366, 378 (1979); Brever $v$ Rockwell International Corp, 40 F3d 1119, 1126-27 (10th Cir 1994); United States v Hartley, 678 F2d 961, 969-72 (11th Cir 1982); Dussouy v Gulf Coast Investment Corp, 660 F2d 594, 602 (5th Cir Nov 1981); Jacobs v Board of Regents, 473 F Supp 663, 670 (S D Fla 1979).

${ }^{41} 584$ F2d 1235, 1256-59 (3rd Cir 1978) (en banc), rev'd on other grounds, 442 US 366,378 (1979).

42 Id at 1257.

43 Id:

[I]t is well-settled that an employer can conspire with his employee . . . The assertion ... must therefore be that incorporation confers on corporate employees an immunity from liability under $\$ 1985$ (3).

We see nothing in the policies underlying $\S 1985(3)$ that would support such an argument.

4 Id at 1258. Specifically, the court observed that few business decisions affect civil rights, and those business decisions that do fall under $\S 1985(3)$ generally do not facilitate competition:

The considerations which shape this antitrust doctrine, rooted in the tension between the policy of ... fostering competition and the interest in not intermeddling unnecessarily in the internal entrepreneurial decisions of companies, do not lie parallel to the balance of concerns embodied in $\S 1985(3) . .$. [W] hile almost any decision by a 
Thus the Novotny court allowed the plaintiffs to proceed with their claims under § 1985(3) notwithstanding that the alleged conspirators were employees of a single corporation. ${ }^{45}$

3. The intracorporate conspiracy doctrine, § 1985(3), and employees of single government entities.

Courts have traditionally subjected state action to a higher level of scrutiny than purely private action. The tradition of scrutinizing state action more closely than private conduct derives from the Fourteenth Amendment, which established that individuals have rights that cannot be abridged by the states. As the Supreme Court explained in Shelley v Kraemer:

The historical context in which the Fourteenth Amendment became a part of the Constitution should not be forgotten. Whatever else the framers sought to achieve, it is clear that the matter of primary concern was the establishment of equality in the enjoyment of basic civil and political rights and the preservation of those rights from discriminatory action on the part of the States. ${ }^{46}$

As a consequence of this mandate, the courts have long agreed that discriminatory state action should be closely monitored to guarantee that all citizens are accorded the equal protection of the laws. ${ }^{47}$

corporation may have an effect on competitors, and thereby come within the potential purview of the antitrust law, ... only a limited number of decisions will impact on "equal protection" and "equal privileges and immunities."

Id at $1258 \mathrm{n} 121$.

45 Id at 1259.

48334 US 1,23 (1948). Although the decision in Shelley specifically dealt with racial discrimination, commentators agree that the Fourteenth Amendment targets discriminatory state action generally, with less attention given to purely private acts. See Richard S. Kay, The State Action Doctrine, the Public-Private Distinction, and the Independence of Constitutional Law, 10 Const Comm 329, 330 (1993) (noting that as a general rule, "the Constitution is especially concerned with the limitation of 'public' power," and less so with the limitation of "private" power).

17 See The Civil Rights Cases, 109 US 3, 13-14 (1883) (Congress can enact legislation to correct defective state laws.); Yick Wo v Hopkins, 118 US 356 (1886) (invalidating city ordinance that enabled government officials to discriminate against Chinese businesses); Hill $v$ Texas, 316 US 400 (1942) (holding state method of selecting grand jury members invalid because the law allowed officials to exclude potential black jurors); Adarand Constructors, Inc. $v$ Pena, 115 S Ct 2097 (1995) (holding federal affirmative action program subject to strict scrutiny because it potentially violated the Fifth Amendment). 
In light of the long tradition of holding discriminatory state action to a higher standard than private action, the intracorporate conspiracy doctrine should not prevent plaintiffs from bringing causes of action under $\S 1985(3)$ to redress harms caused by conspiracies within government entities. To date, however, only one court has explicitly reached this result. In Rebel Van Lines $v$ City of Compton, a federal district court pointed out the longstanding legal tradition of allowing criminal conspiracy charges against employees of government entities. ${ }^{48}$ "Even before the Supreme Court broadened the scope of $\S 1985(3)$ to include purely private conspiracies, the Court had routinely applied the statute to conspiracies within a single governmental entity. ${ }^{\prime \prime 9}$ In support of its contention, the court noted that the Supreme Court has on several occasions allowed criminal conspiracy charges to proceed against employees of single government entities, including members of local police departments and local election board commissioners. ${ }^{50}$

Moreover, the court reasoned that even if private businesses should typically be allowed to make business decisions without being subject to conspiracy liability, this concern does not carry as much weight in litigation involving $\S 1985(3)$ claims against employees of government entities. "Racial discrimination can never further any 'business purpose' of a governmental entity. To apply the intra-corporate conspiracy exception to [§ 1985 claims against employees of] public entities would immunize official policies of discrimination." ${ }^{31}$ Based on these two arguments, the court allowed the plaintiffs to pursue their $\S 1985(3)$ claims against the employees of the City of Compton. ${ }^{52}$

The Rebel Van Lines court stands alone, however, in asserting that the intracorporate conspiracy doctrine does not shield employees of a single government entity from liability under $\S$ 1985(3). Most courts simply adhere to the standard established in

48663 F Supp 786, 792 (C D Cal 1987). Other courts that have decided whether $\S$ 1985(3) reaches conspiracies within government entities have simply relied on the established majority or minority viewpoints. See notes $30-45$ and accompanying text.

19 Rebel Van Lines, $663 \mathrm{~F}$ Supp at 792.

so Id. See United States $v$ Price, 383 US 787, $799-807$ (1966) (applying federal conspiracy statute to Mississippi police department); Screws v United States, 325 US 91 (1945) (remanding for new trial on conspiracy charges against police); United States $v$ Classic, 313 US 299, 322-23 (1941) (Conspiracy statute reaches attempt by commissioners to stop citizens from voting.).

${ }^{31}$ Rebel Van Lines, 663 F Supp at 792-93.

52 Id at 793. 
Dombrowski and bar $\S 1985(3)$ causes of action. ${ }^{53}$ A minority of courts, by contrast, has allowed plaintiffs to bring $\S 1985(3)$ claims against employees of single government entities, but only by applying a broader rule that the intracorporate conspiracy doctrine does not apply to civil rights law. ${ }^{54}$ Thus, despite its historical support, the exception articulated by the court in Rebel Van Lines has failed to gain wide acceptance by the federal courts.

\section{COMMON LAW, THE 42D CONGRESS, AND THE INTRACORPORATE CONSPIRACY DOCTRINE}

The court in Rebel Van Lines was correct both as a matter of legal interpretation and as a matter of policy. The legislative history and purpose of $\S 1985(3)$ indicate that the 42d Congress intended for $\S 1985(3)$ to reach conspiracies within government entities. Moreover, conspiracies within government entities pose a substantial threat to society because they are more likely than individual acts to deny individuals the equal protection of the laws. Applying the intracorporate conspiracy doctrine in this context would undermine the substantive policy goals of $\S$ 1985(3) and contravene congressional intent.

A. The Intracorporate Conspiracy Doctrine and the Common Law: A Rationale for Applying the Doctrine to § 1985(3)?

The decision of a majority of federal courts to apply the intracorporate conspiracy doctrine to $\S 1985(3)$ is difficult to understand and difficult to justify. Most of these courts have blindly followed Dombrowski, which offers little explanation for the doctrine's application. ${ }^{55}$ At least one court, however, has sought to justify the application of the doctrine in the $\S 1985(3)$ context on the ground that the doctrine was established at common law when the $42 \mathrm{~d}$ Congress enacted the $\mathrm{Ku} \mathrm{Klux}$ Klan Act in 1871. In Travis $v$ Gary Community Mental Health Center, Inc., the Seventh Circuit observed that common law courts had long viewed corporations as single, unitary actors. ${ }^{56}$ Courts therefore "looked past the individual acts [of corporate employees] to concentrate

st See Jacobs $v$ Board of Regents, 473 F Supp 663, 670 (S D Fla 1979) (limiting the intracorporate conspiracy doctrine to the antitrust context).

ss See Section I.B.1.

se 921 F2d 108, 110 (7th Cir 1990). 
on the collective decision [of the single corporation]. ${ }^{357}$ Because the $42 \mathrm{~d}$ Congress gave no indication that it wished to abrogate the common law, the court in Travis reasoned that Congress intended for the doctrine to apply to $\S 1985(3) .^{58}$ This reasoning is flawed, however, and its infirmities become apparent upon an examination of the Supreme Court's method for determining when common law rules should influence courts' interpretation of the Ku Klux Klan Act.

\section{B. Determining When to Incorporate the Common Law into § 1985(3)}

The Travis court's reasoning should be evaluated under the Supreme Court's standard, three-factor analysis for incorporating common law norms into $\S 1983$, as articulated and applied in Owen $v$ City of Independence. ${ }^{59}$ In Owen, the Court explained that common law rules should only be incorporated into $\S 1983$ where it can be shown that (1) the plain meaning of the statute did not abrogate the common law rule in question, (2) the rule was indeed established at the time the statute was enacted, and (3) incorporating the common law would not undermine the purpose and intent of the statute. ${ }^{60}$

The standard articulated in Owen should apply to $\S 1985(3)$ because $\S 1985(3)$ and $\S 1983$ are similarly situated both in history and policy. Both statutes were passed as part of the $\mathrm{Ku}$ Klux Klan Act of 1871, an act in which the $42 \mathrm{~d}$ Congress took broad steps to enforce the guarantees of the Fourteenth Amendment. ${ }^{61}$ As such, both statutes share a common contextual history and purpose, ${ }^{62}$ and should be subject to the same analysis regarding the incorporation of common law rules. (1819).

${ }^{57}$ Id, citing Trustees of Dartmouth College $v$ Woodward, 17 US (4 Wheat) 518, 636

921 F2d at 110 .

59445 US 622, 635-56 (1980) (outlining requirements for incorporating common law immunities into $\S 1983$ ). See also Heck v Humphrey, 114 S Ct 2364, 2375 n 1 (1994) (Souter, Blackmun, Stevens, and O'Connor concurring in judgment) (listing the factors used to determine when common law immunities may be incorporated into $\S 1983$ ); City of Newport v Fact Concerts, Inc., 453 US 247, 258-59 (1981) (same).

60 445 US at 635-56.

${ }^{61}$ See Everette Swinney, Suppressing the Ku Klux Klan-The Enforcement of the Reconstruction Amendments 1870-1877 160-65 (Garland 1987) (discussing the provisions of $\S \S 1$ and 2 of the Ku Klux Klan Act, the predecessors of $\S \S 1983$ and 1985(3), respectively); Gormley, 64 Tex L Rev at 536-37 (cited in note 7) (noting that both $\S 1983$ and $\S$ 1985 were designed to enforce provisions of the Fourteenth Amendment).

62 See Gormley, 64 Tex L Rev at 534-40 (cited in note 7). 
The Supreme Court's analysis in Owen suggests that the Travis court improperly incorporated the intracorporate conspiracy doctrine into $\S 1985(3)$. By the same reasoning, Owen also intimates that the intracorporate conspiracy doctrine should not apply to government employees facing liability under $\S 1985(3)$. Although the plain meaning of the statute is ultimately inconclusive as to Congress's intent to abrogate the intracorporate conspiracy doctrine, the doctrine was not established at common law when § 1985(3) was enacted. Moreover, even assuming that it had been established, the doctrine cannot be applied to conspiracies within government entities because doing so would undermine one of the primary purposes of $\S 1985(3)$.

\section{The plain meaning of $\S 1985(3)$.}

Assuming, for the sake of argument, that the intracorporate conspiracy doctrine was established at common law, whether it is abrogated by the plain meaning of $\S 1985(3)$ is not clear. Section 1985(3) provides that an injured party may recover damages:

If two or more persons in any State ... conspire ... for the purpose of depriving, either directly or indirectly, any person or class of persons of the equal protection of the laws, ... or for the purpose of preventing or hindering the constituted authorities of any State... from giving or securing to all persons ... the equal protection of the laws. ${ }^{63}$

The language of the statute arguably supports the positions of both opponents and proponents of the intracorporate conspiracy doctrine in the government entity context. Opponents of its application could argue that Congress clearly intended for the statute to reach any conspiracy that resulted in the denial of the equal protection of the laws. Indeed, the text of the statute does not mention any exceptions and certainly does not state an exception for agreements within corporate or government entities. On this account, applying the intracorporate conspiracy doctrine to government employees would contradict the plain meaning of the statute, as the statute would only be able to reach a portion of all conspiracies to deny individuals the equal protection of the laws.

Opponents of the doctrine might also contend that its application would seriously undermine the logic of $\S 1985(3)$. Protect- 
ing employees of a government entity from liability under $\S$ 1985(3) would lead to the odd result that the statute would reach private conspiracies, but would not reach the often more dangerous conspiracies that occur within government entities.

Proponents of the intracorporate conspiracy doctrine, however, could contend that the preceding analysis misses the point, because $\S 1985(3)$ refers solely to conspiracies. Without any explicit statement to the contrary, proponents could argue, "conspire" must be given its common law meaning. If the intracorporate conspiracy doctrine was established at common law, then the plain meaning of $\S 1985(3)$ indicates that Congress did not intend for the statute to reach agreements between employees of a single corporation or government entity. Because Congress only generally discussed the term "conspire" and made no explicit statement abrogating the intracorporate conspiracy doctrine, one could conclude that Congress did not intend for $\S 1985(3)$ to reach intracorporate agreements.

Since the plain meaning of $\S 1985(3)$ is inconclusive, the next step is to examine whether the intracorporate conspiracy doctrine was established at common law. If so, then one could credibly claim that it should be read into $\S 1985(3)$.

2. The intracorporate conspiracy doctrine at common law.

Unfortunately for proponents of the doctrine, it is not at all clear that the intracorporate conspiracy doctrine was well established at the time $\S 1985(3)$ was passed. Although common law courts viewed the corporation as one entity, ${ }^{64}$ nothing indicates that the courts allowed the corporate entity to shield individuals from liability for legal transgressions (conspiracy or otherwise) they carried out while working for the corporation. Prior to the passage of $\S 1985(3)$, a number of courts held that criminal charges should be allowed against individual employees despite the fact that they committed the alleged crimes on behalf of corporate entities. ${ }^{65}$ Likewise, as early as 1854 , courts had held

B4 Paul v Virginia, 75 US (8 Wall) 168, 181 (1868); Blackstone, 1 Commentaries $* 456$ (cited in note 17).

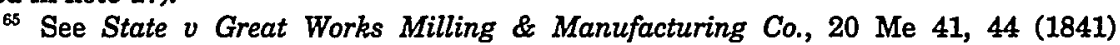
("[W] individuals acting in the business, and not the corporation should be indicted."); State $v$ Patton, 26 NC 16, 17 (1843) (President and directors of a turnpike company, as well as the company itself, may be held liable for allowing the turnpike to fall into disrepair.). See also Brickey, 1 Corporate Criminal Liability § 2:04 at 20-23 (cited in note 8). 
corporate employees liable for conspiracy despite the fact that they were employed by the same corporation. ${ }^{66}$

A number of early cases suggest that the courts were inclined to allow conspiracy charges, both criminal and civil, to proceed against employees of single government entities. For example, in 1854, the Supreme Court of Maine allowed a plaintiff to bring an action for trespass on the case against employees of the local prosecutor's office for conspiring to prosecute without probable cause. ${ }^{67}$ In 1875, the New York Court of Appeals ruled that criminal conspiracy charges would lie against the commissioners of charities of Kings County if the plaintiff could show that the commissioners acted with criminal intent when they made the agreement in question. ${ }^{68}$ Thus, although the relevant precedents are limited in number, they indicate that courts, both immediately prior to and immediately after the passage of $\S$ 1985(3), allowed conspiracy charges to proceed against employees of the same government entity. ${ }^{69}$

Significantly, in 1871, no common law precedent had invoked the intracorporate conspiracy doctrine, or any similar rule, to bar a plaintiff from bringing a cause of action to redress harms caused by a conspiracy among employees of a single corporation. Indeed, the doctrine did not finally take shape until the $1950 \mathrm{~s}$, when courts settled on applying the doctrine to $\S 1$ of the Sherman Act. ${ }^{70}$ In Travis, the Seventh Circuit suggested that the decision in Trustees of Dartmouth College $v$ Woodward ${ }^{71}$ supported its claim that the intracorporate conspiracy doctrine was an established part of the common law when Congress enacted $\S 1985(3) .^{72}$ The decision in Dartmouth College, however,

${ }^{66}$ Page $v$ Cushing, $38 \mathrm{Me}$ 523, 527 (1854) (Trespass on the case allowed against local prosecutor's office employees.). See also State v Donaldson, 32 NJ L 151, 156 (NJ Super Ct 1867) (criminal conspiracy charges upheld against employees of the same corporation who attempted to coerce their employer into firing other employees). Indeed, according to one commentator, it was often the case at the time $\S 1985(3)$ was enacted that individuals could be held liable for wrongs committed on behalf of the corporation. Joel Prentiss Bishop, 1 Commentaries on the Criminal Law $\$ 424$ at 261 (Little, Brown 5th ed 1872).

${ }^{67}$ Page, $38 \mathrm{Me}$ at 527.

68 State $v$ Powell, 63 NY 88, 92 (1875).

$\circledast$ Id. See also Ochs $v$ People, 124 Ill 399, $16 \mathrm{NE} 662,670$ (1888) (upholding conviction of county commissioners for conspiring to award county contracts to favored contractors).

${ }^{30}$ See note 8.

717 US (4 Wheat) 518, 664-66 (1819) (holding that the Constitution bars states from interfering with Dartmouth's original charter from the British Crown).

72 According to the Travis court, Dartmouth College stood for the proposition that common law courts "looked past the individual acts [of corporate employees] to concentrate on the collective decision [of the single corporation]." Travis, 921 F2d at 110, citing Dartmouth College, 17 US (4 Wheat) at 636. 
merely reflects the aforementioned common law view of corporations as single, unitary actors; it does not specifically deal with either conspiracy law or the intracorporate conspiracy doctrine. ${ }^{73}$

Thus, the intracorporate conspiracy doctrine was not established at common law when Congress enacted $\S 1985(3)$. In fact, the precedents indicate that the courts generally allowed conspiracy claims to proceed against employees of the same government entity or corporation. Given this state of the common law in 1871, Congress could hardly have intended for the courts to interpret the intracorporate conspiracy doctrine into the newly enacted civil rights laws.

\section{The legislative history and purpose of $\S 1985(3)$.}

Even if one were to assume that the intracorporate conspiracy doctrine existed at common law when Congress enacted $\S$ 1985(3), the statute's legislative history indicates that the doctrine is at odds with $\S 1985(3)$ 's stated purpose. In passing $\S$ 1985(3), Congress was primarily concerned with the Ku Klux Klan's political power and its ability to conspire to interfere with local and state governments' efforts to provide equal protection of the laws. ${ }^{74}$ One can infer from this concern that Congress intended for $\S 1985(3)$ to reach conspiracies within government

${ }^{73}$ See Dartmouth College, 17 US (4 Wheat) at 636. In Dartmouth College, the Court was faced with the question whether the state, without the college's consent, could alter the college's corporate charter. Id at 626-27. The Court held that because Dartmouth College was a private corporation, its articles of incorporation represented a contract, and could not be altered without mutual agreement. Id at 664-66. The Court briefly discussed the nature of a corporation as a single entity, see id at 636 , but had no occasion to discuss either conspiracy law or the intracorporate conspiracy doctrine.

${ }^{74}$ Several members of the House of Representatives viewed the $\mathrm{Ku} \mathrm{Klux} \mathrm{Klan}$ as a political organization. Representative Stoughton, for example, assessed the political threat as follows:

[I]f this system of [Klan] violence is to continue in the South the Democratic party will secure the ascendancy. If political opponents can be marked for slaughter by secret bands of cowardly assassins who ride forth with impunity ..., it will be fatal alike to the Republican party and civil liberty.

Cong Globe, 42d Cong, 1st Sess 321 (Mar 28, 1871). See also Cong Globe, 42d Cong, 1st Sess 391 (Apr 1, 1871) (Rep Elliot stating that "the design of the Ku Klux is political"); Cong Globe, 42d Cong, 1st Sess 252 (Apr 4, 1871) (Sen Morton stating that crimes committed by Klan intend to "drive those who are supporting the Republican party to abandon their political faith or to flee from the State"). See also Mark Fockele, Comment, $A$ Construction of $\S 1985(3)$ in Light of Its Original Purpose, $46 \mathrm{U}$ Chi L Rev 402, 407-20 (1979) (reviewing legislative history from the 42d Congress showing that Congress viewed the Ku Klux Klan as a political organization). 
entities, as those conspiracies clearly hinder the government's ability to provide individuals with the equal protection of the laws.

Although Congress generally debated the scope of the $\mathrm{Ku}$ Klux Klan Act, it did not specifically address the meaning and scope of the term "conspire." During the debates in both the Senate and the House of Representatives, proponents of the Act referred to conspiracy in general terms. Specifically, they argued that $\S 1985(3)$ should apply to private conspiracies as well as to those involving state action. ${ }^{75}$ Representative Shellabarger, the sponsor of the bill in the House, explained that "[t]he whole design and scope of [§ 1985(3)] was to do this: to provide for the punishment of any combination or conspiracy to deprive a citizen of the United States of such rights and immunities as he has by virtue of the laws of the United States." ${ }^{\text {B6 }}$ Broad statements such as this one indicate that Congress intended $\S 1985(3)$ to reach all conspiracies, including those within government entities.

Of course, this negative inference is not the only possible interpretation of the legislative history. Although the preceding history indicates that Congress intended for $\S 1985(3)$ to reach a broad range of conspiracies, it does not necessarily follow that Congress understood the term conspiracy to include intracorporate conspiracies. Indeed, proponents of the doctrine could point out that the legislative history does not explicitly indicate that Congress understood the term conspiracy as including conspiracies within government or corporate entities. Thus, this portion of the legislative history, while suggestive, is not dispositive.

Despite its failure to define the scope of the term conspiracy, courts should infer that Congress intended the statute to reach conspiracies within government entities in light of its purpose to control the Ku Klux Klan. Applying the intracorporate conspiracy

75 Cong Globe, 42d Cong, 1st Sess 382 (Apr 1, 1871) (Rep Hawley arguing that if Congress cannot reach conspiracies to deprive citizens of their rights, "then the Constitution of the United States is of no value whatsoever").

${ }^{76}$ Id (emphasis added). Representative Cook echoed these sentiments, stating that:

[E]very combination of men by force and intimidation or threat . . to induce the Legislature of a state by unlawful means to deprive citizens of the equal protection of the laws ... [violates] the Constitution of the United States, and may be ... punished by national law. And that ... is the distinct principle on which this bill was founded. 
doctrine to conspiracies within government entities would thwart Congress's intent to prevent the $\mathrm{Ku} \mathrm{Klux} \mathrm{Klan} \mathrm{from} \mathrm{gaining}$ control over parts of the government and to prevent them from using governmental power to deny individuals equal protection of the laws. The legislative history demonstrates that Congress viewed the Klan as a political organization, and that $\S 1985(3)$ was passed, at least in part, out of fear that the Klan would ultimately use its power to control the government. Echoing the concerns of many other members of Congress, Representative Snyder explained:

That immense combinations and conspiracies, bound by terrible oaths, and known under the [name] of the ... Ku Klux Klan . . . exist in the ... southern States, there can be no doubt.

[T]heir object [is] the destruction of Republicanism, the overthrow of the whole system of reconstruction, and the ultimate possession of Government. ${ }^{77}$

Congress thus enacted $\S 1985(3)$ with the primary purpose of preventing the $\mathrm{Ku} \mathrm{Klux}$ Klan from undermining the ability of state and local governments to preserve the rights granted to individuals under the reconstruction laws. ${ }^{78}$

If Congress was indeed concerned about preventing the $\mathrm{Ku}$ Klux Klan from undermining the equal protection efforts of state and local governments, then the intracorporate conspiracy doctrine should not prevent $\S 1985(3)$ from reaching conspiracies within government entities. Applying the doctrine to such conspiracies would severely undercut the effectiveness of the statute. Moreover, it would leave a gap in the statute's application: the

${ }^{77}$ Cong Globe, 42d Cong, 1st Sess app 201 (Apr 6, 1871). Representative Mercur agreed, stating that "[the select committee found that] the Ku Klux organization does exist, has a political purpose, is composed of members of the Democratic or Conservative party, [and] has sought to carry out its purpose by murders, whippings, intimidations, and violence against its opponents." Cong Globe, 42d Cong, 1st Sess app 181 (Apr 6, 1871).

78 Representative Shellabarger argued that the $\mathrm{Ku} \mathrm{Klux}$ Klan sought to roll back the newly recognized individual rights conferred by the reconstruction laws. He explained that "these banded conspirators have the political aims I attribute to them, to wit, to 'trample into dust' these newly-acquired political rights of the freedmen and the constitutions and laws that confer them." Cong Globe, 42d Cong, 1st Sess 517 (Apr 6, 1871). See also Fockele, Comment, $46 \mathrm{U}$ Chi L Rev at 411 (cited in note 74) (noting Klan's purpose of "overthrow[ing] reconstruction policy" in order to "withdraw from the freedmen the equal protection of the laws"). 
statute would reach private conspiracies, but it would not reach conspiracies composed entirely of government employees. It would be ironic indeed if the intracorporate conspiracy doctrine were to make the government, the body charged with enforcing the laws, the only safe haven for those who would conspire to deny others the equal protection of those same laws. The only way for the courts to completely effectuate Congress's intent is to bar the intracorporate conspiracy doctrine from protecting employees of a single government entity in $\S 1985(3)$ cases.

\section{ConsPIRACIES WITHIN GOVERNMENT ENTITIES AND THE SELECTION OF PRECEDENT}

Courts facing the issue of whether the intracorporate conspiracy doctrine should apply to a given body of law must consider whether applying the doctrine generally facilitates or undermines the substantive goals of the body of law in question. When making this determination, courts should look to both criminal and civil case law for guidance, since the doctrine operates in the same technical fashion in each of these contexts. ${ }^{79}$

Courts considering whether to apply the intracorporate conspiracy doctrine to $\S 1985(3)$ inevitably must decide whether to rely on criminal law precedents or antitrust law precedents. In the criminal context, it is well established that the corporate entity cannot shield employees from criminal liability. ${ }^{80}$ In antitrust law, however, the courts uniformly agree that the intracorporate conspiracy doctrine does apply, and that it shields corporate employees from conspiracy liability for intracorporate agreements. ${ }^{81}$ Because the intracorporate conspiracy doctrine has only recently become an issue in civil rights law, courts evaluating it must decide which of these lines of precedent to follow.

79 For example, the intracorporate conspiracy doctrine applies to both criminal and civil actions brought under $\S 1$ of the Sherman Act. See text accompanying note 96. Also see generally Sarah N. Welling, Intracorporate Plurality in Criminal Conspiracy Law, 33 Hastings L J 1155 (1982) (analyzing the different policy justifications for applying the doctrine in criminal, antitrust, and civil rights law). As an additional comparison between civil and criminal law precedents, consider Monroe $v$ Pape, in which the Supreme Court relied on criminal civil rights statutes and case law to interpret 42 USC $\S 1983$, a statute authorizing civil penalties for civil rights violations. 365 US 167, 183-87 (1961), overruled by Monell $v$ New York City Department of Social Services, 436 US 658, 695-96 (1978). See also Novotny, 584 F2d at 1238-39 (relying on criminal conspiracy precedents as grounds for rejecting doctrine in $\S 1985$ (3) context).

${ }^{80}$ See Section III.A.1.

81 See Section III.A.2. 
Reliance on antitrust precedents in the civil rights context is misguided. ${ }^{82}$ Courts that apply the intracorporate conspiracy doctrine to $\S 1985(3)$ argue that the doctrine serves to protect the integrity of the corporate decision-making process. ${ }^{83}$ Without such protection, these courts reason, virtually every discussion between employees about business policy or strategy could be deemed a conspiracy. ${ }^{84}$ This concern, however, is outweighed by the significant dangers posed by conspiracies among government employees. Furthermore, government employees do not need the intracorporate conspiracy doctrine to protect the integrity of their decision-making process; unlike employees of private corporations, government employees already receive sufficient protection from the common law doctrine of qualified immunity to civil liability. ${ }^{85}$

\section{A. The Historical Treatment of the Intracorporate Conspiracy} Doctrine in Criminal and Antitrust Law

1. The intracorporate conspiracy doctrine in criminal law.

Courts today uniformly reject the intracorporate conspiracy doctrine in criminal conspiracy cases and routinely hold government employees and employees of single corporations liable for criminal conspiracies. ${ }^{86}$ Although it is difficult to identify a single case that established this rule (of not applying the doctrine in criminal conspiracy cases), a number of landmark cases outline the reasoning behind the ultimate rejection of the intracorporate conspiracy doctrine in criminal conspiracy law.

Both federal and state courts reject the intracorporate conspiracy doctrine in criminal conspiracy law because the purpose

${ }_{82}$ Other commentators agree. See Milton Handler and Thomas A. Smart, The Present Status of the Intracorporate Conspiracy Doctrine, 3 Cardozo L Rev 23, $72-75$ (1981); Lawrence C. McQuade, Conspiracy, Multicorporate Enterprises, and Section 1 of the Sherman Act, 41 Va L Rev 183, 184-88 (1955).

83 See, for example, Travis, 921 F2d at 110 (arguing that intracorporate discussions lie outside the domain of $\S 1985$ ).

Bs Id.

${ }^{85}$ See Harlow $v$ Fitzgerald, 457 US 800, 815-19 (1982) (explaining concept and parameters of common law qualified immunity); 63A Am Jur 2d Public Officers and Employees §§ 358-70 at 924-40 (1984 \& Supp 1995) (same).

${ }_{85}$ See, for example, United States $v$ Mosley, 238 US 383, 386 (1915) (conspiracy between two county election board members); Mininsohn $v$ United States, 101 F2d 477, 478 (3d Cir 1939) (conspiracy between corporation and employees); United States $v$ Hartley, 678 F2d 961, 972 (11th Cir 1982) (same); United States v Classic, 313 US 299, 322 (1941) (conspiracy between election officials); Bell $v$ City of Milwaukee, 746 F2d 1205, 1253-68 (7th Cir 1984) (conspiracy to cover up facts behind a killing by a police officer). 
served by applying the common law rule that corporations are single, unitary actors is outweighed by the inherent danger posed by criminal conspiracies. Generally, the single, unitary actor rule is invoked to force corporations to take financial responsibility for the harms they or their employees cause. ${ }^{87}$ In criminal conspiracy law, however, the group danger posed by conspiratorial agreements between corporate employees is too great to allow the corporate entity to shield the employees from liability. ${ }^{88}$ In short, the need to punish corporate employees for the group danger posed by their criminal conspiracies outweighs the value of regarding corporations as single actors.

In Standard Oil Co. $v$ State, for example, the Supreme Court of Tennessee explained why it could not allow the corporate entity to shield corporate employees from liability for criminal conspiracy. ${ }^{89}$ Although the employees were acting on behalf of the corporation, they still maintained individual juridical identities and thus were legally responsible for their actions. In a spirited opinion, the court reasoned that to exonerate corporate employees from criminal conspiracy charges would be to declare that corporate employees are "mere tools" of their employers "without minds" and without a sense of responsibility for their deeds. "[T]he result would be that those whose minds conceived and planned and whose hands consummated a crime would not be within the reach of the law and would escape punishment. This cannot be." ${ }^{90}$ Consequently, the court held that individual employees retain personal responsibility for their own criminal actions and should not be able to hide behind the corporate entity. ${ }^{91}$

Commentators also agree that the intracorporate conspiracy doctrine does not shield corporate employees from liability for criminal conspiracy. ${ }^{92}$ Scholars have argued that the courts

${ }^{87}$ See Hartley, 678 F2d at 970 (Corporation must "shoulder financial responsibility" for negligent acts.).

${ }_{83}$ Id. See also Dussouy $v$ Gulf Coast Investment Corp, 660 F2d 594, 603-04 (5th Cir Nov 1981) (finding that state law rejects intracorporate conspiracy doctrine even in antitrust context).

117 Tenn 618, 100 SW 705, 716-18 (1907).

so Id at 717-18.

91 Id. See also United States v Consolidated Coal Co., 424 F Supp 577, 581 (S D Ohio 1976) (Individual can make own decisions, so therefore an employee can conspire with a corporation.).

${ }_{82}$ See, for example, Brickey, 1 Corporate Criminal Liability $\S 6: 21$ at 217 (cited in note 8) (Intracorporate conspiracy doctrine does not extend to criminal cases.); Welling, 33 Hastings $L \mathrm{~J}$ at 1191-1201 (cited in note 79) (arguing that allowing criminal conspiracies to be found among corporate employees best upholds goals of conspiracy law). 
should hold corporate employees liable for criminal conspiracy because doing so better serves the purposes and goals of conspiracy law..$^{93}$ Other commentators reason that since intracorporate conspiracies pose the same threats to society as conspiracies formed outside corporations, courts should hold the conspirators equally liable in both cases. ${ }^{94}$ Finally, some commentators simply reason that since corporate employees are individual actors, they are guilty of conspiring if they join together in criminal activity. ${ }^{95}$ However, regardless of the justification, both courts and commentators agree that the intracorporate conspiracy doctrine should not shield employees of the same government entity or private corporation from liability for criminal conspiracy.

2. The intracorporate conspiracy doctrine and antitrust law.

In contrast to their approach to criminal conspiracy law, courts uniformly agree that the intracorporate conspiracy doctrine applies to both criminal and civil actions under $\S 1$ of the Sherman Act, which prohibits conspiracies and contracts in restraint of trade. ${ }^{96}$ Although the statute does not specify whether it reaches conspiracies within corporations in addition to conspiracies between corporations, courts today apply the intracorporate conspiracy doctrine to limit the statute's scope to conspiracies between corporations. ${ }^{97}$

93 Welling, 33 Hastings $L \mathrm{~J}$ at 1199 (cited in note 79) (stating that holding corporate employees liable for criminal conspiracy serves the end of punishing the employees for posing increased danger to society through group criminal activity and noting that conspiracies make complex crimes more feasible and more difficult to detect).

94 Developments in the Law, Criminal Conspiracy, 72 Harv L Rev 920, 953 (1959) ("[T]he essence of conspiracy rationales are present to the same extent as if the same persons combined their resources without incorporation.").

${ }_{95}$ Hoffman, Comment, $72 \mathrm{Ky} \mathrm{L} \mathrm{J} \mathrm{at} 233$ (cited in note 6).

${ }_{96}$ Section 1 of the Sherman Act provides: "Every contract, combination . . . or conspiracy, in restraint of trade . . . is declared to be illegal." 15 USC \& 1. In Copperweld Corp $v$ Independence Tube Corp, the Supreme Court held that $\S 1$ does not apply to wholly intracorporate agreements. 467 US 752, 767 (1984). Since both civil and criminal liability for conspiracies to restrain trade hinge on whether the defendant violated $\S 1$, the intracorporate conspiracy doctrine applies to both criminal and civil actions under the Act. See 15 USC $\S \S 1,15$ (1994).

${ }^{87}$ See Copperweld, 467 US at 767. Prior to Copperweld, at least two courts had suggested that employees of a single corporation could constitute the plurality of actors necessary to a conspiracy to violate the antitrust laws. See Patterson $v$ United States, 222 F 599, 619 (6th Cir 1915); White Bear Theater Corp v State Theater Corp, 129 F2d 600, 606 (8th $\mathrm{Cir}$ 1942). However, to the extent that these cases did suggest antitrust intracorporate conspiracies were possible, they have been overruled by Copperweld, which clearly held that intracorporate agreements do "not raise the antitrust dangers that $\$ 1$ [of the Sherman Act] was designed to police." 467 US at 769. Moreover, White Bear and 
Courts have offered two justifications for applying the intracorporate conspiracy doctrine in the antitrust context. First, some courts reason that the group danger targeted by the Sherman Act only arises when independent economic actors, such as separate corporations, join forces to restrain trade. ${ }^{98}$ Because the Sherman Act seeks to foster competition, group danger only arises under $\S 1$ when corporations that were previously competing and pursuing independent economic goals conspire to restrain trade. Agreements of this nature pose a threat to society because they are anticompetitive and tend to restrict output and raise prices. ${ }^{99}$

Agreements between employees of the same corporation, by contrast, do not pose the same dangers. Rather than being anticompetitive, agreements between employees of the same corporation may actually facilitate competition by enhancing the ability of the corporation to compete in the marketplace..$^{100}$ Moreover, agreements between employees of the same corporation do not present the specter of independent economic actors joining forces behind a common anticompetitive goal. ${ }^{101}$ Because intracorporate agreements do not pose the same group dangers as other agreements, the intracorporate conspiracy doctrine properly shields corporate employees from antitrust conspiracy liability. ${ }^{102}$

Patterson likely have little precedential value in any event since neither directly addresses the intracorporate conspiracy doctrine. See Welling, 33 Hastings $L$ J at 1165-67 (cited in note 79).

${ }^{98}$ See, for example, Copperweld, 467 US at 769.

99 Id at 768-69.

100 Id at 769.

101 As the Court in Copperweld explained:

[A]n internal "agreement" to implement a single, unitary firm's policies does not raise the antitrust dangers that $\S 1$ [of the Sherman Act] was designed to police. The officers of a single firm are not separate economic actors pursuing separate economic interests, so agreements among them do not suddenly bring together economic power that was previously pursuing divergent goals. Coordination within a firm is as likely to result from an effort to compete as from an effort to stifle competition.

Id.

102 Id at 767. See also The Attorney General's National Committee to Study the Antitrust Laws 31 (US GPO 1955):

Restraining trade is not illegal, but only contracting, combining and conspiring in restraint of trade. Since ... the normal commercial conduct of a single trader acting alone may restrain trade, many activities of any business could be interdicted were joint action solely by the agents of a single corporation acting on its behalf itself held to constitute a conspiracy in restraint of trade. 
As a second justification for applying the intracorporate conspiracy doctrine in antitrust law, courts reason that without the doctrine, conspiracy law would reach even the most mundane, day-to-day business decisions. Corporate employees should be free to have discussions about how the corporation will carry out its business affairs. ${ }^{103}$ If the Sherman Act reached these types of discussions, it might deter corporate employees from discussing actions or making decisions that benefitted their corporation and actually increased the level of competition in the market. ${ }^{104}$ The intracorporate conspiracy doctrine therefore protects the freedom of corporate employees to confer and make business decisions on behalf of the corporation. ${ }^{105}$

Commentators disagree on the wisdom of applying the intracorporate conspiracy doctrine to the Sherman Act. While some agree with the current rule that applies the doctrine wholesale to antitrust conspiracy cases, ${ }^{106}$ others argue for a more individualized approach that would require courts to evaluate both intra- and intercorporate agreements to determine if those agreements resulted in unreasonable restraints of trade. ${ }^{107}$ Although courts have disagreed, advocates of the individualized approach argue that it would enable the courts to reach all agreements that hamper the competitive market, thereby better upholding the purpose behind the Sherman Act. ${ }^{108}$

${ }^{103}$ For example, the court in Nelson Radio \& Supply Co. $v$ Motorola, Inc. responded to the plaintiff's claim that the Sherman Act reached agreements among employees of the same corporation with incredulity: "Surely discussions among [corporate employees] concerning the price at which the corporation will sell its goods, the quantity it will produce, the type of customers or market to be served, or the quality of goods to be produced do not result ... in a conspiracy in unlawful restraint of trade under the Sherman Act." 200 F2d 911, 914 (5th Cir 1952).

104 Id. See also Copperweld, 467 US at 769.

105 See Nelson Radio, 200 F2d at 914.

106 See, for example, George W. Stengel, Intra-Enterprise Conspiracy Under Section 1 of the Sherman Act, 35 Miss L J 5, 8 (1963); William S. Brewbaker III, Antitrust Conspiracy Doctrine and the Hospital Enterprise, 74 BU L Rev 67, $72-76$ (1994); Denise D. Daggett, Note, Antitrust-Section 1 of the Sherman Act and the Intra-Enterprise Doctrine-Copperweld Corp. v. Independence Tube Corp., 21 Wake Forest L Rev 463, 481-83 (1986).

${ }^{107}$ See Peter J. Alessandria, Comment, Intra-Entity Conspiracies and Section I of the Sherman Act: Filling the "Gap" after Copperweld Corp. v. Independence Tube Corp., 34 Buff L Rev 551, 586-92 (1985); Welling, 33 Hastings L J at 1167 (cited in note 79); Richard V. Barndt, Two Trees or One?-The Problem of Intra-Enterprise Conspiracy, 23 Mont L Rev 158, 186-87 (1962); S. John Goodwin, The Demise of the Intra-Enterprise Conspiracy Doctrine: Flexible Antitrust Enforcement Policy Abandoned in a Maze of Economic Certainty - Copperweld Corp. v. Independence Tube Corp., 104 S.Ct. 2731 (1984), 60 Wash L Rev 757, 776-79 (1985).

${ }_{108}$ Single corporations have the ability in some circumstances to restrain trade by 


\section{B. Government Entities, $\S 1985(3)$, and the Selection of Precedent}

The preceding analysis demonstrates that courts must weigh two factors when deciding whether the intracorporate conspiracy doctrine should apply to a given body of law. On one hand, courts must consider the magnitude of the group danger employees of the same corporation pose to society when they form conspiracies. If the danger is significant, then the scales tip heavily toward relying on criminal conspiracy precedents and allowing conspiracy claims against employees of the same corporation. On the other hand, courts must consider whether allowing such claims would hamper the employees' ability to confer and make routine business decisions. If corporate decision making would be severely hampered by the prospect of these claims, then the scales tip toward relying on antitrust precedents and applying the intracorporate conspiracy doctrine.

In the civil rights context, these considerations counsel against the application of the doctrine. ${ }^{109}$ At first glance, the Novotny court's reasoning appears decisive because the justifications for applying the intracorporate conspiracy doctrine in antitrust law appear inapposite..$^{10}$ As the Novotny court stated, the antitrust concerns "do not lie parallel" to the concerns in civil rights law. ${ }^{111}$ Specifically, applying the doctrine to $\S 1985(3)$ frustrates the statute's ability to target the group danger arising from conspiracies. Applying the doctrine to antitrust law, by contrast, does not frustrate $\S 1$ of the Sherman Act, because there, group danger arises only when corporations conspire. In addition, $\S 1985$ (3) does not directly relate to business activities and thus does not pose a substantial threat to competition and business

hampering their competitors' ability to trade on the market. Note, Intra-Enterprise Conspiracy Under Section 1 of the Sherman Act: A Suggested Standard, 75 Mich L Rev 717, 732-34 (1977).

${ }_{109}$ Some courts and commentators have expressed the concern that without proper limitation, the scope of $\S 1985(3)$ would become so broad as to convert the statute into a "federal tort law." See Griffin, 403 US at 101-02; McLellan $v$ Mississippi Power \& Light Co., 545 F2d 919, 940-41 (5th Cir 1977) (Godbold dissenting); Note, 92 Harv L Rev at 484 (cited in note 6). However, the reach of $\S 1985$ (3) can be limited by means less harsh than the absolute bar imposed by the intracorporate conspiracy doctrine. For example, some courts require the plaintiff to prove that the conspiracy was "motivated by 'some racial, or perhaps otherwise class-based, invidiously discriminatory animus behind the conspirator's action." United Brotherhood of Carpenters, Local 610 v Scott, 463 US 825, 829 (1983), quoting Griffin, 403 US at 102.

110584 F2d at 1256-59. See Section I.B.2.

$111584 \mathrm{~F} 2 \mathrm{~d}$ at $1258 \mathrm{n} 121$. 
decision making. ${ }^{112}$ While allowing $\S 1$ of the Sherman Act to reach intracorporate discussions might hamper corporate decision making, allowing $\S 1985(3)$ to reach discussions within government entities should not pose this problem because government officials receive sufficient protection through the common law doctrine of qualified immunity. ${ }^{113}$ The differences between antitrust and civil rights law and the factors generally balanced by the courts make the choice clear: the intracorporate conspiracy doctrine should not apply in $\S 1985(3)$ cases.

Despite this reasoning, most courts have declined to follow Novotny. ${ }^{114}$ There are, however, two additional reasons why the intracorporate conspiracy doctrine should not shield government employees from liability under $\S 1985(3)$. First, conspiracies within government entities pose a significant group danger, and $\S$ 1985(3) provides the most effective means for addressing that danger. Second, the intracorporate conspiracy doctrine is not necessary to protect decision making within government entities; government officials already enjoy qualified immunity to civil liability.

1. Government entities, group danger, and conspiracies to violate civil rights.

The intracorporate conspiracy doctrine should not apply when government employees face liability under $\S 1985(3)$ because conspiracies within government entities pose a substantial danger to society and because $\S 1985(3)$ provides the most reliable remedy for individuals injured by these conspiracies. Both Congress and the judiciary have long traditions of carefully monitoring the actions of local and state governments, and through $\S$ 1985(3) they have sought to provide individuals with federal recourse if their local or state government denies them equal protection of the laws. It would be inconsistent with this goal to apply the intracorporate conspiracy doctrine to $\S 1985(3)$, thereby denying injured parties one of the most reliable means for combating and deterring the group danger that results when government officials conspire to violate an individual's civil rights.

114 See, for example, Runs After $v$ United States, 766 F2d 347, 354 (8th Cir 1985) (following majority rule); Travis, 921 F2d at 110 (same). See also Section I.B.1. 
a. The long tradition of protecting individuals from harm caused by the government. Throughout the debates preceding the ratification of the Fourteenth Amendment, several state legislators and members of Congress argued in favor of strict controls on the exercise of state power. ${ }^{115}$ New York Attorney General J.H. Martindale made one of the most compelling cases in favor of controlling such power, contending that state and local governments could not be allowed to accord different sets of rights to different classes of individuals. ${ }^{116}$ Thus, the Fourteenth Amendment provides individuals with a right of national citizenship, which in turn entitles them to protection from action by state or local governments intended to deny them access to fundamental rights. ${ }^{117}$

Moreover, the federal judiciary has consistently held that Congress may pass legislation to enforce the Fourteenth Amendment and control civil rights violations by government officials. ${ }^{118}$ Between the ratification of the Fourteenth Amendment and the Supreme Court's decision in Griffin to extend the reach of $\S 1985(3)$ to cover private conspiracies, ${ }^{119}$ the judiciary held firm in its view that the Fourteenth Amendment conferred on Congress broad power to legislate against governmental violations of civil rights. ${ }^{120}$

115 During the debate and ratification of the Fourteenth Amendment, a number of Congressmen expressed support of the Amendment as a tool for preventing abuses of government power. See, for example, Cong Globe, 39th Cong, 1st Sess 2766 (May 23, 1866) (Sen Howard stating that "[t]he great object of the first section of [the] amendment is [ ] to restrain the power of the States and compel them at all times to respect these great fundamental guarantees"); Cong Globe, 40th Cong, 2d Sess 514-15 (Jan 14, 1868) (Rep Bingham stating that "when [any state] shall in its madness . . . refuse [to provide any citizen] any of the rights which pertain to American citizenship ... . [ [the Fourteenth Amendment] will be redress for [that] wrong"). See also Joseph B. James, The Framing of the Fourteenth Amendment 160 (Illinois 1956) (quoting Rep Bingham explaining the Amendment as "impos[ing] a limitation upon the States to correct their abuses of power").

118 Letter from J.H. Martindale to John Sherman (May 12, 1866), quoted in William E. Nelson, The Fourteenth Amendment: From Political Principle to Judicial Doctrine 128 (Harvard 1988).

117 See Swinney, Suppressing the Ku Klux Klan at 15-16 (cited in note 61).

11 See, for example, The Civil Rights Cases, 109 US 3, 11 (1883) (Fourteenth Amendment allows Congress to provide "redress against the operation of [discriminatory] State laws."); United States $v$ Cruikshank, 92 US 542, 555 (1875) (Fourteenth Amendment empowers Congress "to see that states do not deny" equal protection.). See also US Const, Amend XIV, \& 5 ("The Congress shall have power to enforce, by appropriate legislation, the provisions of this article.").

119 See text accompanying notes 27-29.

120 Interestingly, the judiciary allowed Congress to regulate civil rights violations by the government even during times when it was generally hostile to civil rights legislation. See Ex Parte Virginia, 100 US 339, 348 (1879) (Fourteenth Amendment probibits state 
Prior to its decision in Griffin, the Supreme Court had adhered to a restrictive view of Congress's power to legislate under the Fourteenth Amendment, both when considering civil rights legislation generally and when considering $\S 1985(3)$ in particular. After the Reconstruction, the Court routinely struck down civil rights laws intended to regulate private conduct. ${ }^{121}$ In doing so, however, the Court consistently indicated that it would uphold laws aimed solely at regulating civil rights violations committed by states or by state officials. ${ }^{122}$ In the Civil Rights Cases, for example, the Supreme Court explained its general interpretation of the scope of Congress's powers under the Fourteenth Amendment:

[The Fourteenth Amendment] does not authorize Congress to create a code of municipal law for the regulation of private rights; but to provide modes of redress against the operation of State laws, and the action of State officers, executive or judicial, when these are subversive of the fundamental rights specified in the amendment. ${ }^{123}$

Even under this restrictive view of the Fourteenth Amendment, then, the Court clearly recognized that the Fourteenth Amendment authorizes Congress to legislate against civil rights violations by the government and its officials.

In keeping with this philosophy, the Supreme Court indicated in Collins $v$ Hardyman that despite $\S 1985(3)$ 's inability to reach private conspiracies, it could reach conspiracies involving government officials. ${ }^{124}$ The Court based this decision on the language of $\S 1985$ (3), concluding that the statute applies primarily to conspiracies involving state officials, as these would be the conspiracies most likely to deprive individuals of the equal protection of the law. ${ }^{125}$

If the Court in Collins correctly identified the target of $\S$ 1985(3) as conspiracies to deny individuals the equal protection of the laws, then the intracorporate conspiracy doctrine should

judges from excluding black jurors.); Cruikshank, 92 US at 555 (Fourteenth Amendment prevents states from denying citizens equal protection of the laws.); United States $v$ Harris, 106 US 629, 638-39 (1882) (same); Civil Rights Cases, 109 US at 11 (same).

121 See note 24.

122 See, for example, Civil Rights Cases, 109 US at 11 (noting that Fourteenth Amendment targets state action and not acts by private individuals); Cruikshank, 92 US at 555 (Fourteenth Amendment guarantees protection only against discriminatory state action.).

1023 US 3, 11 (1883).

${ }^{124} 341$ US at 661-62.

${ }^{225}$ Id. 
not apply to $\S 1985(3) .{ }^{126}$ Applying the doctrine to conspiracies within government entities does not make sense because conspiracies within government entities pose an even greater group danger than private conspiracies-government officials generally have the power to directly and effectively deny individuals equal protection of the laws. Application of the intracorporate conspiracy doctrine would therefore undermine the primary goal of $\S$ 1985(3) by preventing the statute from reaching the conspiracies that posed the greatest group danger to society.

\section{b. Section 1985(3)-the best statute for reaching} government conspiracies to violate civil rights. Application of the intracorporate conspiracy doctrine to claims against government employees would also emasculate the most reliable means for combating the group danger posed by conspiring government employees. Although the courts generally allow plaintiffs to bring conspiracy claims under $\S 1983$ of the Ku Klux Klan Act, ${ }^{127} \S$ 1983 is less effective than $\S 1985$ as a means of reaching government conspiracies because it requires that the harm be caused by an individual acting "under color of state law."128 Specifically, $\S 1983$ is unreliable to this end because in order to establish a conspiracy, the plaintiff must prove " 1 ) the existence of a conspiracy involving state action and 2) a deprivation of civil rights in furtherance of the conspiracy by a party to the conspiracy." ${ }^{29}$ Section 1983, therefore, differs from $\S 1985(3)$ in that it requires state action in addition to a "deprivation of civil rights in furtherance of the conspiracy." 130

${ }_{128}$ Although the Court in Griffin rejected Collins's holding that $\S 1985(3)$ does not apply to private individuals, it agreed with Collins that the statute targeted conspiracies to deprive individuals of the equal protection of the laws. Griffin, 403 US at 95-102.

12742 USC § 1983 (1994). See Mizell v North Broward Hospital District, 427 F2d 468, $472-73$ (5th Cir 1970); Mosher v Saalfeld, 589 F2d 438, 441 (9th Cir 1978); Ames v Vaureck, 356 F Supp 931, 940 (D Minn 1973); Blake v Town of Delaware City, 441 F Supp 1189 , 1198-99 (D Del 1977). The courts may, however, apply the intracorporate conspiracy doctrine to conspiracies under $\$ 1983$ as well. Brever $v$ Rockwell International Corp, 40 F3d 1119, 1126-27 (10th Cir 1994) (noting that several circuits "have extended the intracorporate conspiracy doctrine to actions under sections 1983 and $1985^{\prime \prime}$ ).

128 Section 1983 was passed in conjunction with $\$ 1985(3)$ and reads, in pertinent part: "Every person who, under color of any statute ... of any State . . . subjects, or causes to be subjected, any citizen of the United States ... to the deprivation of rights, privileges, or immunities secured by the Constitution and laws, shall be liable to the party injured in an action at law .... 42 USC $\S 1983$ (emphasis added).

129 Pfannstiel $v$ City of Marion, 918 F2d 1178, 1187 (5th Cir 1990).

130 Id. 
Suppose, for example, that the public defenders in City A conspire to deny African-American criminal defendants effective assistance of counsel. Section 1983 would provide the hypothetical criminal defendants no remedy, as the Supreme Court has held that acts by public defenders do not constitute state action. ${ }^{131}$ Section 1985(3), however, would provide a remedy unless the court applied the intracorporate conspiracy doctrine.

Because the Supreme Court has been inconsistent in interpreting the "under color of state law" requirement, § 1983 offers, at best, an unreliable means for redressing harms caused by conspiracies between government employees. In United States $v$ Classic, an action alleging a criminal civil rights violation, the Court defined this phrase to encompass actions where government officials act in performance of their official duties. ${ }^{132}$ The Court offered the following open-ended definition of civil rights violations committed under color of state law: "Misuse of power, possessed by virtue of state law and made possible only because the wrongdoer is clothed with the authority of state law, is action taken 'under color of' state law."133 Were this apparently broad definition of "under color of state law" settled doctrine, $\S 1983$ might provide a viable alternative to $\S 1985(3)$ in reaching government conspiracies.

Unfortunately, though, the definition is far from settled. For example, in Polk County $v$ Dodson, the Court held that a public defender does not act under color of state law when representing one of his or her clients in a criminal proceeding. ${ }^{134}$ The Dodson Court reasoned that although the state pays the public defender's salary, the public defender's allegiance lies first and foremost with his clients. ${ }^{135}$ After Dodson, then, despite Classic's sweeping rhetoric, mere employment by the state is not dispositive of whether an individual acts under color of state law. Instead, a court following Dodson must also consider the extent to which

${ }^{131}$ Polk County v Dodson, 454 US 312, 319 (1981).

132313 US 299, 326 (1941). See also Screws v United States, 325 US 91, 110 (1945) (adhering to Classic definition of "under color of state law" in context of criminal civil rights action); Monroe v Pape, 365 US 167, 187 (1961) (approving Classic/Screws definition of "under color of state law" and extending it to $\$ 1983$ actions).

133 Classic, 313 US at 326.

134 454 US 312, 319 (1981). In Dodson, the plaintiff brought a § 1983 claim alleging ineffective assistance of counsel against the public defender assigned to his case after the public defender moved to withdraw as counsel on the grounds that the plaintiff's appeal was frivolous. Id at 314 .

${ }^{133}$ Id at 318. 
the employee is obligated to adhere to the goals set by the state. ${ }^{136}$

In contrast, in West $v$ Atkins the Court held that a private physician working as an independent contractor in a state prison acts under color of state law when treating prison inmates. ${ }^{137}$ The Court distinguished Dodson by noting that while physicians, like attorneys, may exercise independent judgment in treating their patients, they nevertheless still serve in a cooperative capacity with the state. ${ }^{138}$ Rather than focusing on the terms of the physician's employment or the amount of professional discretion that the physician was allowed to exercise, the West Court posited that the proper focus should be the function the physician serves within the system and whether the goals of that function are aligned with the goals of the state. Because the state and the physician acted with a common goal, the West Court concluded that the physician acted under color of state law. ${ }^{139}$

In light of the persisting uncertainty surrounding the phrase "under color of state law," courts should not allow the intracorporate conspiracy doctrine to prevent $\S 1985(3)$ from reaching conspiracies within government entities. ${ }^{140}$ The Court's inconsistent treatment of the "under color of state law" requirement creates uncertainty as to whether $\S 1983$ can redress injuries caused by conspiracies to violate civil rights. Section 1985(3), however, has no such requirement, and thus would provide plaintiffs with a more reliable means of seeking redress for these injuries.

\footnotetext{
136 Id at $319-20$.

${ }^{137} 487$ US 42, 56-57 (1988).

${ }^{238}$ Id at 50-51.

139 Id at 55-57.
}

140 Recent case law demonstrates that the precise definition of the term "under color of state law" remains unclear. In Gallagher $v$ "Neil Young Freedom Concert", for example, the Tenth Circuit held that independently hired security guards were not acting under color of state law while providing security for a concert held in a state university arena. 49 F3d 1442, 1450 (10th Cir 1995). This result seems inconsistent with the outcome in West, where independently hired physicians were held to act under color of state law because they serve in a cooperative capacity with the state. 487 US at 56-57. The situation in Gallagher seems to pass the West test (the goals of the security guards-to control the crowds and protect the public-are presumably aligned with the goals of the state university), and yet the cases come out differently. This contradiction highlights the unsettled nature of this body of law. 
2. Common law immunity and the protection of governmental decision making.

One argument in favor of applying the intracorporate conspiracy doctrine-often compelling in the antitrust context-is that the doctrine is necessary to protect the decision-making processes of corporate entities. However, as applied to government entities in the civil rights context, this argument is unpersuasive. Specifically, the intracorporate conspiracy doctrine should not be applied to shield employees of government entities from liability under $\S 1985$ (3) because the common law rules of absolute and qualified immunity sufficiently and independently protect government employees and their decision-making processes.

The common law immunity doctrines are court-developed rules that, when applicable, shield government employees from civil liability for injuries they inflict on individuals while acting in their official capacities. ${ }^{141}$ Section 1985(3) likely incorporates the common law rules of immunity. In Owen, the Supreme Court held that these rules applied to $\S 1983$, which was passed in tandem with $\S 1985(3){ }^{142}$ Because the decision-making and other official functions of government employees are already protected by common law immunities, application of $\S 1985(3)$ should not chill legitimate government decision making. Qualified immunity strikes the proper balance (between punishing conspiracies and protecting decision making) by only allowing liability when the officials knew or should have known their actions violated the victim's civil rights. Applying the intracorporate conspiracy doctrine here would only serve to upset this balance by extending protection to clearly improper acts by officials.

In addition to qualified immunity, several types of government employees enjoy absolute immunity from civil liability when they act in their official capacities. For instance, the Su-

${ }^{141}$ See generally David Achtenberg, Immunity Under 42 U.S.C. $\S 1983$ : Interpretive Approach and the Search For Legislative Will, $86 \mathrm{Nw}$ U L Rev 497 (1992) (describing common law immunities and analyzing the approaches the Supreme Court has taken to immunity law).

${ }^{142}$ Specifically, the Owen Court held that since common law immunities had been established and accepted long before the enactment of $\S 1983$, and since Congress did not explicitly abrogate the common law, the statute implicitly incorporated the immunities into its parameters. 445 US at 637-38. Since $\S 1985(3)$, like $\S 1983$, was passed as part of the Ku Klux Klan Act, its scope is also limited by the common law immunities that existed at the time of its enactment. See text accompanying notes 55-62. Common law immunities frustrate neither the plain language nor the purpose of $\S 1985(3)$, and thus must be read into the statute. See id. 
preme Court has held that legislators are absolutely immune to lawsuits for civil damages, provided that the alleged harmful conduct occurred while the legislator was carrying out a legislative function. ${ }^{143}$ Likewise, judges enjoy absolute immunity from lawsuits claiming damages caused by an act the judge took while carrying out his or her judicial functions. ${ }^{144}$ Finally, certain officials in the executive branch enjoy absolute immunity from civil liability. ${ }^{145}$

Most government employees, however, enjoy only a qualified immunity from civil liability for acts undertaken in the scope of their employment. Qualified immunity protects government employees from civil liability as long as the government official can objectively demonstrate that he acted in good faith. ${ }^{146}$ Government employees satisfy this burden by proving that a reasonable person would not have known that his actions violated the victim's statutory or constitutional rights. ${ }^{147}$ Thus, government employees who can demonstrate that they were not negligent in violating an individual's rights are immune from liability for civil damages. ${ }^{148}$

The intracorporate conspiracy doctrine should, therefore, not shield government employees from liability under $\S 1985(3)$ because the common law rules of qualified and absolute immunity sufficiently protect the ability of government employees to make decisions. Government employees who exercise judicial and legislative functions are absolutely immune to civil liability and are, therefore, free to make decisions without fear of $\S 1985(3)$. Individuals injured by their decisions, meanwhile, normally have recourse in that they may appeal legislative and judicial decisions to the courts.

The decision making of government employees who enjoy only qualified immunity from civil liability is likewise sufficiently

${ }^{143}$ Eastland v United States Servicemen's Fund, 421 US 491, 507 (1975).

${ }^{144}$ Stump v Sparkman, 435 US 349, 356-57 (1978).

${ }_{145}$ See Butz v Economou, 438 US 478, 515 (1978) (absolute immunity for prosecutors and those exercising similar authority); Nixon $v$ Fitzgerald, 457 US 731, 754 (1982) (absolute immunity in civil suits for President of the United States for his official acts).

${ }^{146}$ Harlow $v$ Fitzgerald, 457 US 800, 818 (1982).

147 Id. As the Court explained, "government officials performing discretionary functions, generally are shielded from liability for civil damages insofar as their conduct does not violate clearly established statutory or constitutional rights of which a reasonable person would have known." Id (citations omitted).

${ }_{143}$ The courts may accord slightly higher protection to certain high-level government employees who exercise more complex discretionary decision making. Scheuer $v$ Rhodes, 416 US 232, 246 (1974). 
protected. These employees need only fear liability if the facts demonstrate that the employees, at the time they acted, should have been aware that they were violating an individual's clearly established constitutional or statutory rights. The rules for qualified immunity thus strike a fair balance between allowing injured parties to bring suit and protecting the decisions of government employees.

\section{CONCLUSION}

The intracorporate conspiracy doctrine should not apply to $\S$ 1985(3) claims against employees of single government entities. Such an application would run contrary to the legislative history and purpose of $\S 1985(3)$, which indicate that Congress intended to reach conspiracies within government entities. Moreover, statutes such as $\S 1985(3)$ are enacted to enforce the guarantees of the Fourteenth Amendment and, therefore, explicitly target the kind of dangers that civil rights conspiracies within government entities precipitate. The intracorporate conspiracy doctrine serves little purpose in this context because it forces courts to ignore the fact that government employees pose a substantial threat to society when they conspire to violate an individual's civil rights. These concerns are particularly compelling given that the intracorporate conspiracy doctrine is largely unnecessary in the government entity context; the decision-making and other official functions of government employees already enjoy significant protection under the common law doctrines of absolute and qualified immunity to civil liability for harms resulting from official decisions. Finally, and most importantly, judicial rejection of the intracorporate conspiracy doctrine in this context would broaden the range of possible remedies and causes of action available to individuals who have been injured by governmental conspiracies to violate their civil rights. 